\title{
ॠUSGS
}

science for a changing world

Prepared in cooperation with the GRAND CANYON MONITORING AND RESEARCH CENTER

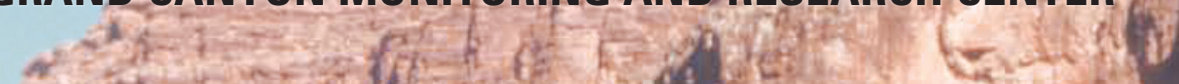

Flow Velocity and Sediment Data Collected D. During 1990 and 1991 at National Canyon, Colorado River, Arizoná
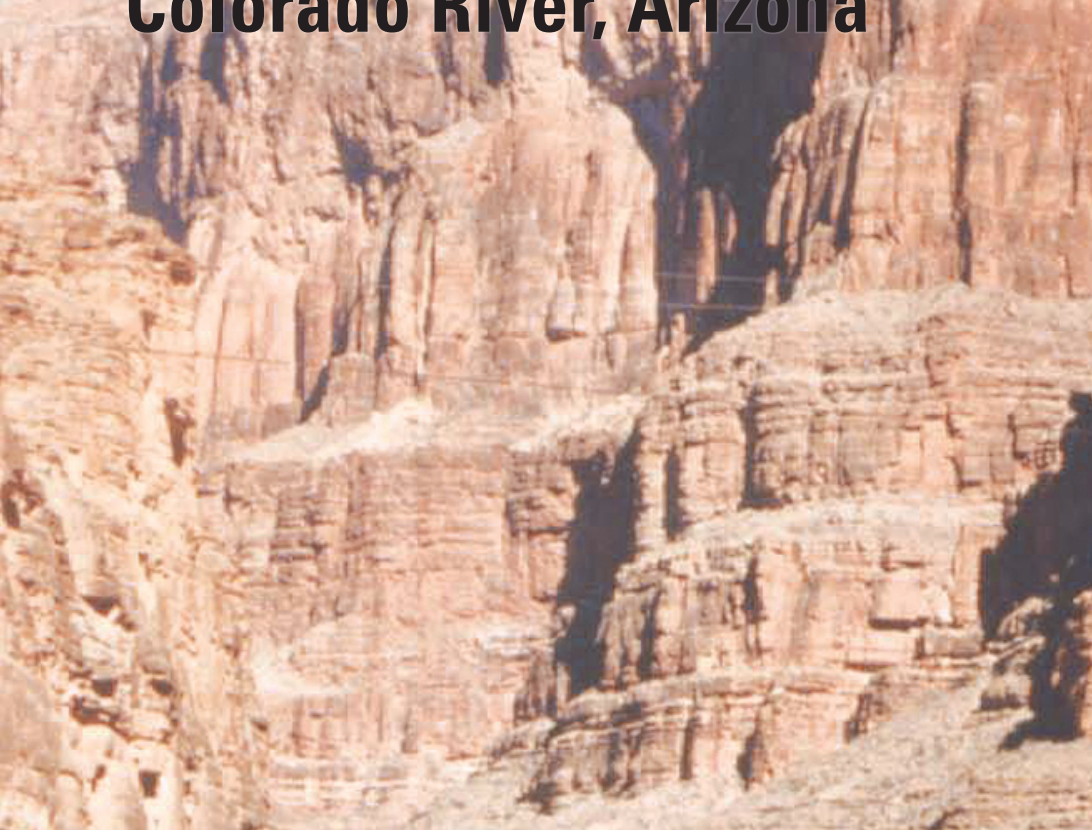

10
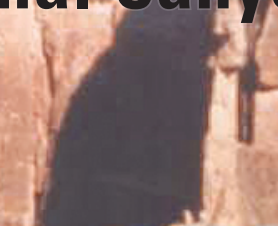

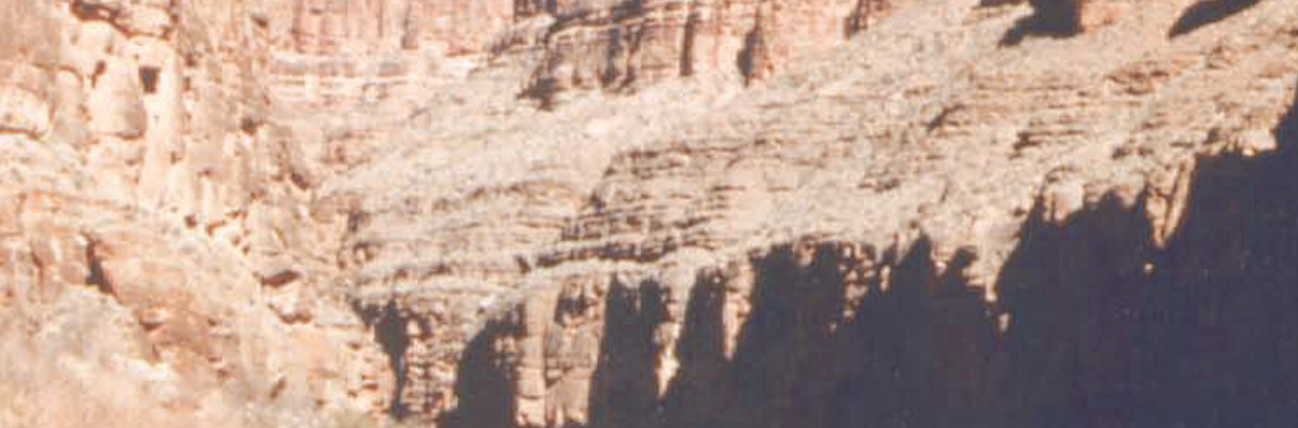

S
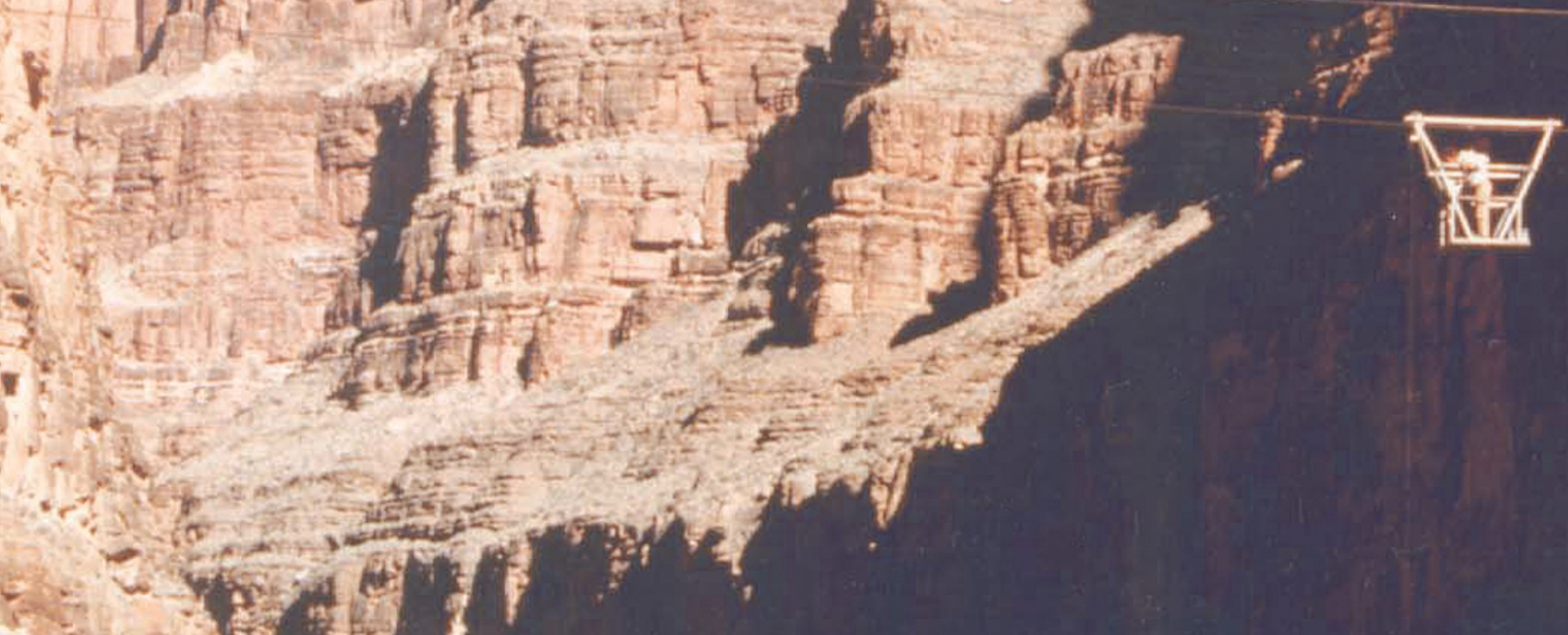

Data Series 246

U.S. Department of the Interior

U.S. Geological Survey 
Inside Front Cover

This page left blank intentionally. 


\section{Flow Velocity and Sediment Data Collected During 1990 and 1991 at National Canyon, Colorado River, Arizona}

By Nancy J. Hornewer and Stephen M. Wiele

Prepared in cooperation with the Grand Canyon Monitoring and Research Center

Data Series 246 


\section{U.S. Department of the Interior DIRK KEMPTHORNE, Secretary}

\section{U.S. Geological Survey \\ Mark D. Myers, Director}

\section{U.S. Geological Survey, Reston, Virginia: 2007}

For product and ordering information:

World Wide Web: http://www.usgs.gov/pubprod

Telephone: 1-888-ASK-USGS

For more information on the USGS--the Federal source for science about the Earth, its natural and living resources, natural hazards, and the environment:

World Wide Web: http://www.usgs.gov

Telephone: 1-888-ASK-USGS

Any use of trade, product, or firm names is for descriptive purposes only and does not imply endorsement by the U.S. Government.

Although this report is in the public domain, permission must be secured from the individual copyright owners to reproduce any copyrighted materials contained within this report.

Suggested citation:

Hornewer, N.J., and Wiele, S.M., 2007, Flow velocity and sediment data collected during 1990 and 1991 at National Canyon, Colorado River, Arizona: U.S. Geological Survey Data Series 246, 11 p. 


\section{Contents}

Abstract
Introduction.
Purpose and Scope
Deknowledgments
$\quad$ Releases from Glen Canyon Dam
Flow, Velocity Profiles, Suspended and Bed Sediment Samples, and Sample Analysis
References Cited

\section{Figures}

1. Map showing location of National Canyon study area on the Colorado River in Grand Canyon, Arizona

2. Hydrographs of discharge at U.S. Geological Survey streamflowgaging stations Colorado River below Glen Canyon Dam (gage number 09379910) and Colorado River above National Canyon near Supai (gage number 09404120) during Research Flows A-F.

\section{Tables}

1. Number of cross sections, point-velocity measurements, and types and total numbers of sediment samples collected and analyzed from seven research flows in 1990 and 1991

\section{Conversion Factors}

\begin{tabular}{|c|c|c|}
\hline Multiply & By & To obtain \\
\hline \multicolumn{3}{|c|}{ Length } \\
\hline inch (in.) & 25.4 & millimeter $(\mathrm{mm})$ \\
\hline foot $(\mathrm{ft})$ & 0.3048 & meter $(\mathrm{m})$ \\
\hline mile (mi) & 1.609 & kilometer $(\mathrm{km})$ \\
\hline \multicolumn{3}{|c|}{ Flow rate } \\
\hline cubic foot per second $\left(\mathrm{ft}^{3} / \mathrm{s}\right)$ & 0.02832 & cubic meter per second $\left(\mathrm{m}^{3} / \mathrm{s}\right)$ \\
\hline
\end{tabular}


This page left blank intentionally. 


\title{
Flow Velocity and Sediment Data Collected During 1990 and 1991 at National Canyon, Colorado River, Arizona
}

\author{
By Nancy J. Hornewer and Stephen M. Wiele
}

\section{Abstract}

During 1990 and 1991, a series of research flows were released from Glen Canyon Dam. Data collected at the streamflow-gaging station on the Colorado River above National Canyon near Supai from that period have been compiled and entered into the U.S. Geological Survey database. The data consist of measurements of suspendedsediment concentration and sand sizes in suspension, sand sizes of streambed sediment, and velocity of the Colorado River above National Canyon near Supai streamflow-gaging site. Velocity and sediment data are available upon request from the Arizona Water Science Center and from the U.S. Geological Survey water-quality database (http://waterdata. usgs.gov/az/nwis/qw).

\section{Introduction}

During 1990 and 1991, a series of research flows were released from Glen Canyon Dam (figure 1). The releases were part of a series of studies done in cooperation with the U.S. Bureau of Reclamation and the U.S. Geolgical Survey (USGS) to determine the effect of releases from the dam on the river corridor between Glen Canyon Dam (river mile -15.5) and Lake Mead (river mile 276.5). Locations along the river are indicated by river mile (RM) below Lees Ferry, which is designated RM 0, (Breedlove and Mietz, 2002). During the releases, suspended sediment and bed material were sampled to study sediment transport at the Colorado River above National Canyon near Supai (USGS gage number 09404120) streamflow-gaging station (referred to as the National gage in this report), located at RM 166. Velocity and sediment data are available upon request from the Arizona Water Science Center and from the USGS water-quality database (http://waterdata. usgs.gov/az/nwis/qw).

\section{Purpose and Scope}

This report presents the availability of suspendedsediment concentration and sand sizes in suspension, sand sizes of streambed sediment, and velocity data collected at the National gage, 166 miles below Lees Ferry (182 miles below Glen Canyon Dam) on the Colorado River, during the research flows in 1990 and 1991. Field work consisted of measuring velocity profiles and collecting suspendedsediment and bed-sediment samples. The units used in this report are the units in which the data are stored in the database and are also the units used by Grand Canyon researchers and managers.

\section{Acknowledgments}

Julia Graf, John Gray, Greg Fisk, and Bob Hart (USGS) provided information regarding field methods used during the data collection. Ted Melis and Scott Wright of the USGS Grand Canyon Monitoring and Research Center (GCMRC) supported this report and the GCMRC provided funding for publication. The Bureau of Reclamation through the Glen Canyon Environmental Studies funded the data collection and sample analysis. Finally, much credit and appreciation is owed to the many individuals who worked diligently and arduously to collect sediment samples during the 1990-1991 research flows.

\section{Description of the National Gage Study Area}

The reach in which the National Canyon streamflowgaging station was located is relatively straight and of uniform width compared to most of the rest of the Colorado River in Grand Canyon. The channel is deeply entrenched in bedrock, and the channel margins are lined with talus slopes. The debris fan at the mouth of National Canyon, 0.25 mile downstream from the streamflow-gaging station, forms a hydraulic control for the mainstem Colorado River in the sampling section for the discharges released during the research flows. The channel bottom typically was covered with a sand layer with dunes during 1990 and 1991 (Christiansen, 1993). The National gage was operated between July 31, 1983, and April 18, 1993, and again from March 7, 1996, through April 25, 1996. 


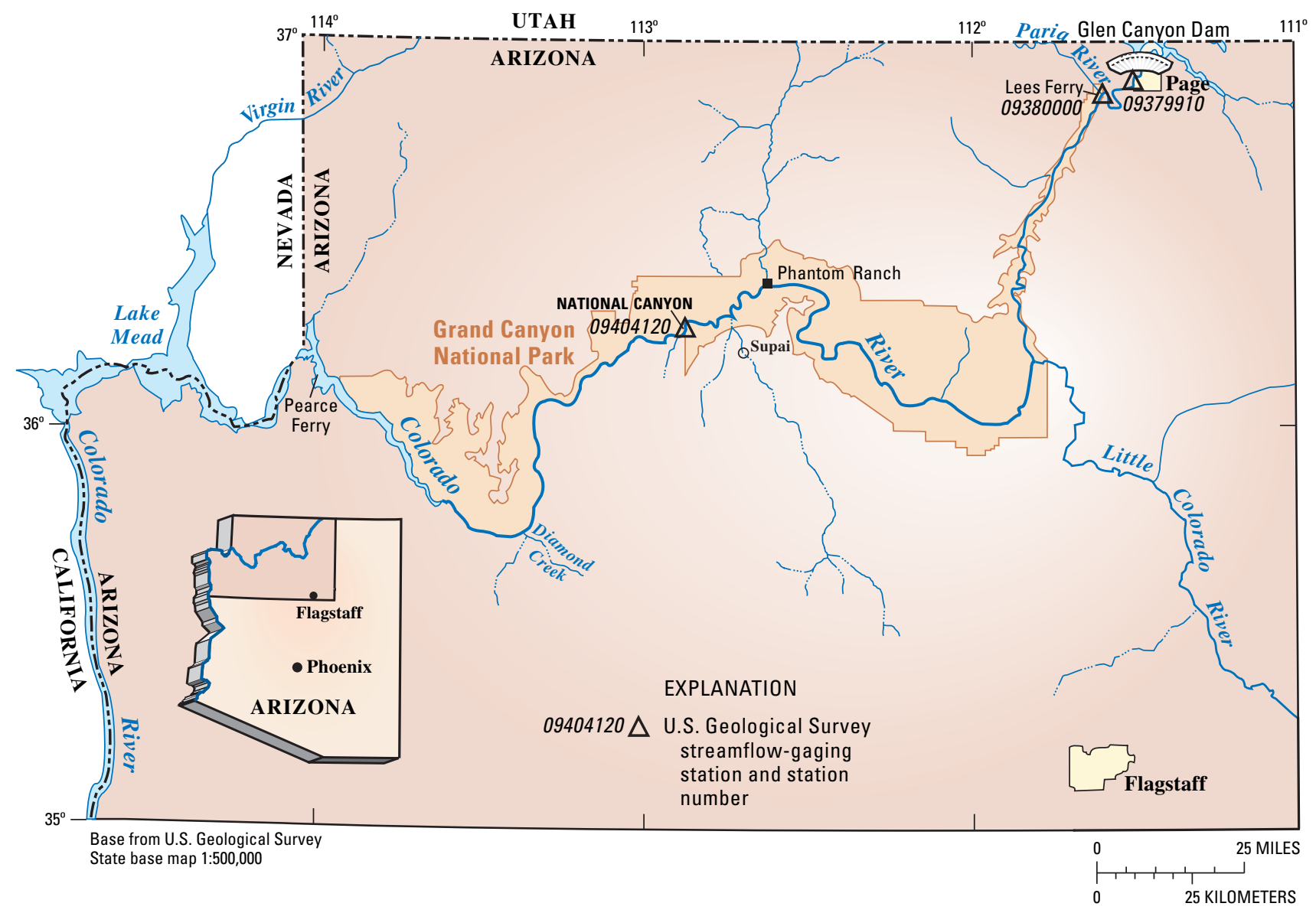

Figure 1. Location of National Canyon study area on the Colorado River in Grand Canyon, Arizona. 


\section{Releases from Glen Canyon Dam}

The research releases in 1990 and 1991 consisted of steady or fluctuating flows preceded and followed by steady flows lasting 3 days. The releases were designated with letters A-F (figure 2). Sediment was sampled and analyzed for releases as follows: A, December 17, 1990-December 27, 1990; B, December 31, 1990-January 10, 1991; C, January 28, 1991-February 7, 1991; D, May 6, 1991-May 16, 1991; E, May 20, 1991-May 30, 1991; F, July 1, 1991-July 11, 1991; and G, July 15, 1991-July 25, 1991. Discharge records for flows A, B, C, D, E, F, and G from the Colorado River below Glen Canyon Dam streamflow-gaging station (USGS gage number 09379910) and National gage are available upon request from the Arizona Water Science Center.

\section{Flow, Velocity Profiles, Suspended and Bed Sediment Samples, and Sample Analysis}

The number of cross sections, point-velocity measurements, and types and total numbers of sediment samples collected and analyzed for each of the research flows are shown in table 1. Discharge at National gage was computed following standard USGS procedures from a record of stage and a stage-discharge rating curve developed with the method described by Rantz and others (1982a, 1982b) and Rote and others, 1997.

J.B. Graf (hydrologist, U.S. Geological Survey, written commun., 1991) described the suspended sediment sampling and velocity profile measurements:

During the highest flows in the 1991 measurements, samples were collected and velocity measurements made at 11 locations across the channel. These were at stations 60, 75, 95, 110, 130, 145, 160, 175, 190, 210 , and 225. The locations were selected to define sections of approximately equal discharge. At each station, samples were collected and measurements made at points 0.5, 1.5, 3.0, 6.0, $12.0 \mathrm{ft}$ from the channel bottom and at a point about $2 \mathrm{ft}$ below the water surface. If flow depth exceeded $24 \mathrm{ft}$, an additional sample was collected at a point $18 \mathrm{ft}$ from the channel bottom. For most sample suites, 77 samples or velocity measurements were then collected ( 7 points at 11 stations). Point velocity measurements were made at each point where a suspended-sample was collected.

The station locations noted above are in feet, referenced from the left bank. It took approximately 1-2 hours to collect a full set of suspended-sediment samples or point-velocity measurements from all station points across the channel (referred to as 1 cross section). The spacing between station locations was determined at 11,500 cfs to approximate the equal-discharge-increment (EDI) method (Richard Siedeman, hydrologist, U.S. Geological Survey, written commun., 1991; EDI method described by Guy and Norman, 1970). Sediment samples were collected and velocity measurements were made from a cableway. A P61 sampler and methods described by Edwards and Glysson (1999) were used to collect suspendedsediment samples.

Suspended-sediment samples were analyzed by the USGS Sediment Laboratory at Cascades Volcano Observatory. The samples were sieved to separate sand $(>0.0625 \mathrm{~mm})$ from silt $(<0.0625 \mathrm{~mm})$, and the sand-size distribution was determined with a visual-accumulation tube (Guy, 1969).

Bed sediment was sampled with a BM-54 sampler at stations about $15 \mathrm{ft}$ apart (Richard Siedeman, hydrologist, U.S. Geological Survey, written commun., 1991). Samples were analyzed at the USGS National Research Program Sediment Lab in Tucson, Arizona. 

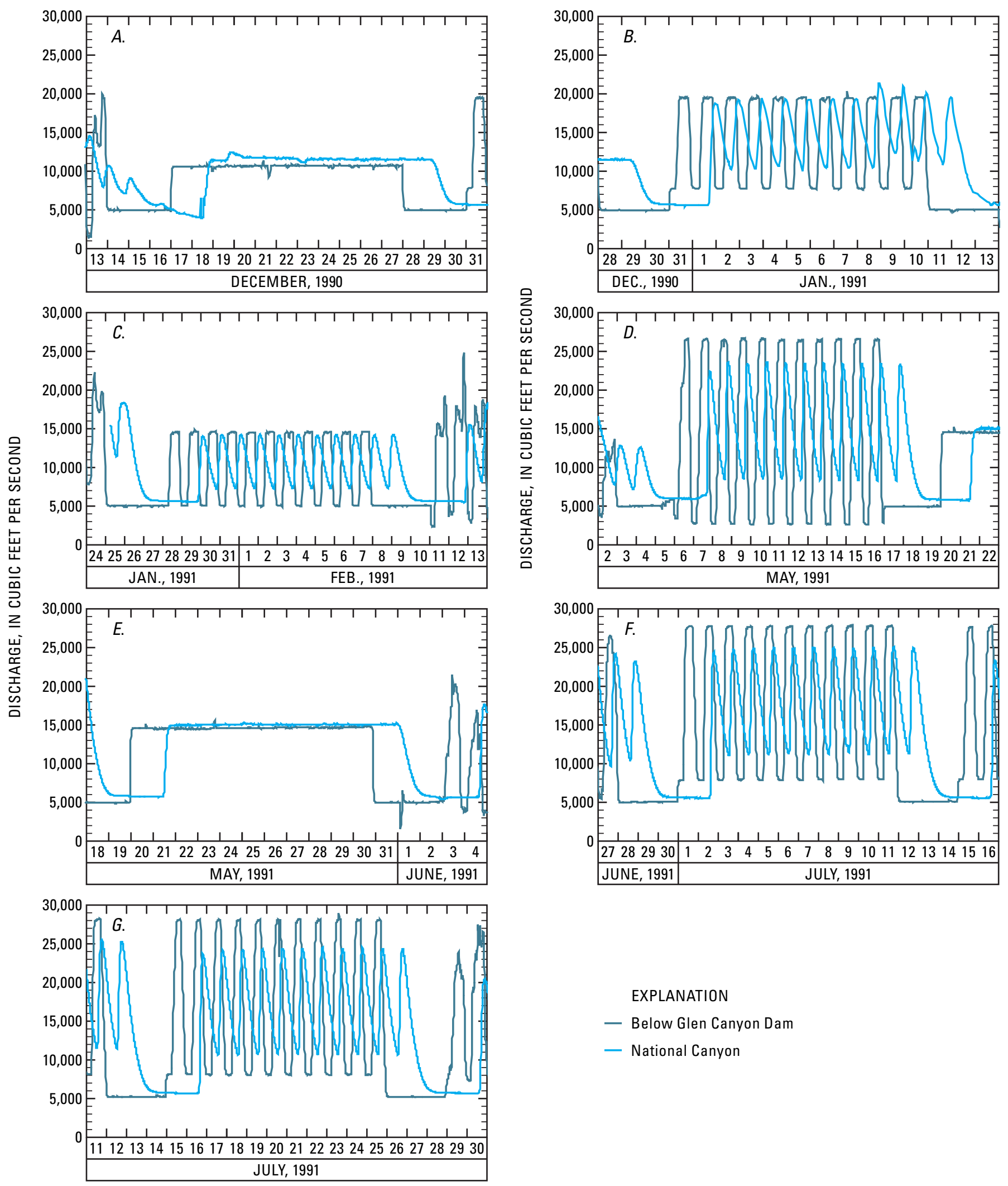

EXPLANATION

- Below Glen Canyon Dam

- National Canyon

Figure 2. Hydrographs of discharge at U.S. Geological Survey streamflow-gaging stations Colorado River below Glen Canyon Dam (gage number 09379910) and Colorado River above National Canyon near Supai (gage number 09404120) during Research Flows A-F. 
Table 1. Number of cross sections, point-velocity measurements, and types and total numbers of sediment samples collected and analyzed from seven research flows in 1990 and 1991

$[---$, no data $]$

\begin{tabular}{|c|c|c|c|c|c|c|c|c|c|c|c|c|c|c|}
\hline Data & $\begin{array}{l}\text { Number } \\
\text { of cross } \\
\text { sections }\end{array}$ & $\begin{array}{l}\text { Total } \\
\text { number } \\
\text { of } \\
\text { samples }\end{array}$ & $\begin{array}{l}\text { Number } \\
\text { of cross } \\
\text { sections }\end{array}$ & $\begin{array}{c}\text { Total } \\
\text { number } \\
\text { of } \\
\text { samples }\end{array}$ & $\begin{array}{l}\text { Number } \\
\text { of cross } \\
\text { sections }\end{array}$ & $\begin{array}{c}\text { Total } \\
\text { number } \\
\text { of } \\
\text { samples }\end{array}$ & $\begin{array}{l}\text { Number } \\
\text { of cross } \\
\text { sections }\end{array}$ & $\begin{array}{c}\text { Total } \\
\text { number } \\
\text { of } \\
\text { samples }\end{array}$ & $\begin{array}{l}\text { Number } \\
\text { of cross } \\
\text { sections }\end{array}$ & $\begin{array}{l}\text { Total } \\
\text { number } \\
\text { of } \\
\text { samples }\end{array}$ & $\begin{array}{l}\text { Number } \\
\text { of cross } \\
\text { sections }\end{array}$ & $\begin{array}{l}\text { Total } \\
\text { number } \\
\text { of } \\
\text { samples }\end{array}$ & $\begin{array}{l}\text { Number } \\
\text { of cross } \\
\text { sections }\end{array}$ & $\begin{array}{c}\text { Total } \\
\text { number } \\
\text { of } \\
\text { samples }\end{array}$ \\
\hline Flow & \multicolumn{2}{|c|}{ A } & \multicolumn{2}{|c|}{ B } & \multicolumn{2}{|c|}{ C } & \multicolumn{2}{|c|}{ D } & \multicolumn{2}{|c|}{ E } & \multicolumn{2}{|c|}{$\mathbf{F}$} & \multicolumn{2}{|c|}{ G } \\
\hline $\begin{array}{l}\text { Velocity } \\
\text { (point } \\
\text { measurements) }\end{array}$ & 2 & 60 & 25 & 472 & 13 & 382 & 18 & 644 & 7 & 297 & 17 & 1,179 & 17 & 1,157 \\
\hline $\begin{array}{l}\text { Suspended sediment-split } \\
\text { (analyzed for sand/silt split) }\end{array}$ & --- & --- & --- & --- & 19 & 428 & --- & --- & --- & --- & 7 & 510 & 8 & 492 \\
\hline $\begin{array}{l}\text { Suspended sediment-full } \\
\text { (analyzed for grain size } \\
\text { distribution) }\end{array}$ & --- & --- & --- & -- & 3 & 54 & 2 & 65 & --- & --- & --- & --- & 12 & 695 \\
\hline Bed sediment & 2 & 10 & 4 & 38 & 2 & 11 & --- & --- & 4 & 33 & --- & --- & --- & --- \\
\hline
\end{tabular}




\section{References Cited}

Breedlove, M.J., Mietz, S., 2002, A map guide to the Colorado River in the Grand Canyon: U.S. Geological Survey, USGS Grand Canyon Monitoring and Research Center technical report.

Christiansen, T., 1993, Suspended sediment transport in the Colorado River: Seattle, University of Washington, unpublished master's thesis, $113 \mathrm{p}$.

Edwards, T.K., and Glysson, G.D., 1999, Field methods for measurement of fluvial sediment: U.S. Geological Survey Techniques of Water-Resources Investigations, chap. C2, book $3,89 \mathrm{p}$.

Guy, H.P., 1969, Laboratory theory and methods for sediment analysis: U.S. Geological Survey Techniques of WaterResources Investigations, chap. C1, book 5, 58 p.
Guy, H.P., and Norman, V.W., 1970, Field methods for measurement of fluvial sediment: U.S. Geological Survey Techniques of Water-Resources Investigations, chap. C2, book 3, 59 p.

Rantz, S.E., and others, 1982a, Measurement and computation of streamflow: Volume 1, Measurement of stage and discharge: U.S. Geological Survey Water-Supply Paper 2175.

Rantz, S.E., and others, 1982b, Measurement and computation of streamflow: Volume 2, Computation of discharge: U.S. Geological Survey Water-Supply Paper 2175.

Rote, J.J., Flynn, M.E., and Bills, D.J., 1997, Hydrologic data, Colorado River and major tributaries, Glen Canyon Dam to Diamond Creek, Arizona, water years 1990-95: U.S. Geological Survey Open-File Report 97-250, 474 p. 
Manuscript approved for publication, January 19, 2007.

Prepared by the U.S. Geological Survey Reports Section, Tucson, Arizona.

USGS Publishing staff Tracey L. Suzuki, Technical Editor John Callahan, Illustrator

For more information concerning the research in this report, contact the Arizona Water Science Center Director,

U.S. Geological Survey, 520 N. Park Ave., Suite 221

Tucson, AZ 85719

http://az.water.usgs.gov 
This page left blank intentionally. 
Inside Back Cover

This page left blank intentionally. 
Hornewer and Wiele-FLOW VELOCITY AND SEDIMENTATION DATA COLLECTED DURING 1990 AND 1991 AT NATIONAL CANYON, COLORADO RIVER, ARIZONA—U.S. Geological Survey Data Series 246 